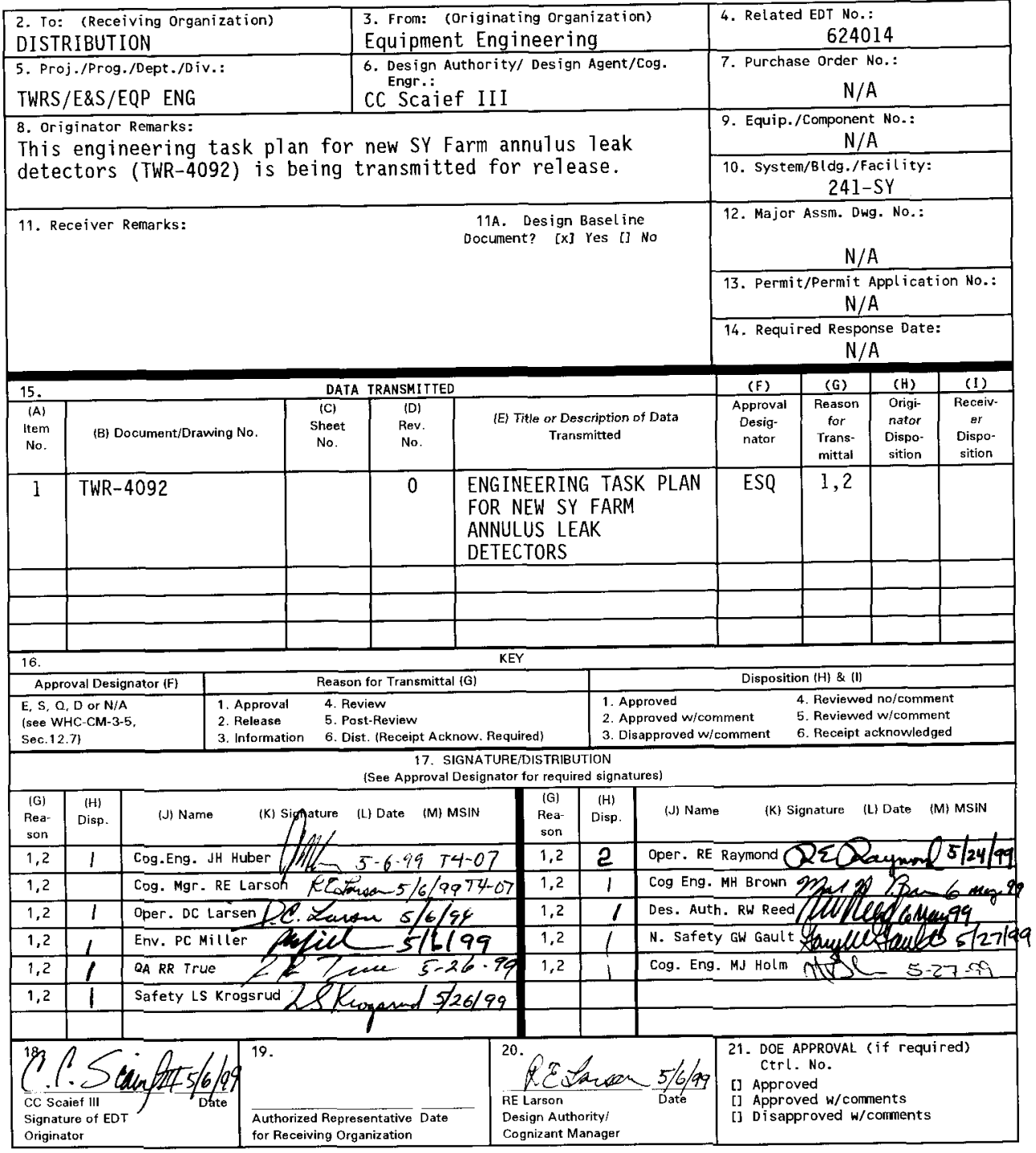

BD-7400-172-2 (05/96) GEF097 


\section{ENGINEERING TASK PLAN FOR NEW SY FARM ANNULUS LEAK DETECTORS}

\section{Scajef III}

Lockheed Martin Hanford Corporation, Richland, WA 99352

U.S. Department of Energy Contract DE-AC06-96RL13200
EDT/ECN: EDT $\rightarrow 624017$
Org Code: 74700
UC: 510
Charge Code: 106773
B\&R Code: EW3120071
Total Pages: 11

Key Words: leak detection, annulus, tank, requirements, testing

Abstract: This document provides a plan for installing a new annulus leak detection device into the annuli of the waste storage tanks in SY Farm. Requirements are included.

IRADEMARK DISCLAIMER. Reference herein to any specific comercial product, process, or service by trade naine, trademark, manufacturer, or otherwise, does not necessarily constitute or imply its endorsement, recommendation, or favoring by the United States Government or any agency thereof or its contractors or subcontractors.

Printed in the United States of America. To obtain copies of this document, contact: Document Control Services, P.0. Box 950, Mailstop H6-08, Richland WA 99352, Phone (509) 372-2420; Fax (509) 376-4989.

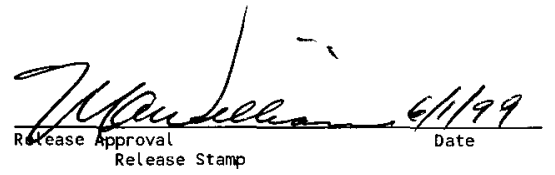

Approved for Public Release 
TWR-4092, REV 0

\section{ENGINEERING TASK PLAN FOR NEW SY FARM}

ANNULUS LEAK DETECTORS

TABLE OF CONTENTS

1.0 INTRODUCTION . . . . . . . . . . . . . . . . . . 1

2.0 WORK SCOPE ......................... 1

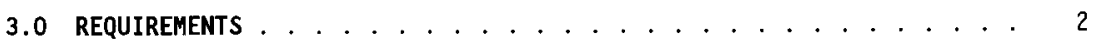

4.0 TASK DESCRIPTIONS . . . . . . . . . . . . . . . . . . . . . . . . 4

5.0 COST AND SCHEDULE ....................... 6

6.0 REFERENCES ...................... . . 6

$7.0 \underset{\text { APPENDIX A }}{\text { APPENDIX }} \cdot \ldots \ldots \ldots \ldots$

APPENDIX B . . . . . . . . . . . . . . . . . . . 


\subsection{INTRODUCTION}

This task plan provides the work activity description and requirements for installation of additional annulus leak detectors in the three SY Farm Double Shel1 Tanks (DST). The tanks presently have one conductivity probe in each tank annulus for leak detection. The other 25 DSTs have three annulus conductivity probes in each tank as well as a CAM. This activity will initially install one Enraf-Nonius 854 ATG level gauge in the annulus of Tank SY-102 for verification that the gauge will meet the requirements for annulus leak detection. After successful demonstration, an additional eight gauges will be installed. Upon completion, each SY Farm tank will have three annulus leak detectors.

If the testing in Tank SY-102 reveals that the 854 Enraf gauge is unsuitable for annulus leak detection, another technology will be deployed to achieve three detectors per tank.

The existing SY annulus leak detectors use a reel type conductive tape with a weighted plummet or probe at the end. The reel tapes are marked with graduations providing a measure of probe depth. The probes are set at a fixed level above the annulus floor and provide alarming if conductivity is detected. The set point is generally $1 / 2$ inch or less above the floor. The reel type conductivity devices are fabricated from a Hanford design and are referred to as Flake boxes (the name of the original designer of the instrument). Many of the existing Flake boxes are in poor condition and need to be replaced. Fabrication of a new device is expensive. This as well as problems with operation and reliability has resulted in a search for a new leak detection instrument.

The Enraf 854 level gauge has been used successfully at Hanford for in-tank waste level measurement for over five years and is the primary leak detection method for Single Shel1 Tanks (SST). Most of the earlier Food Instrument Company (FIC) reel type conductivity level gauges have been replaced by the 854. The 854 operates on the principal of buoyancy and uses a displacer suspended by a small diameter steel alloy wire. In liquid, the 854 measures level to an accuracy of 0.04 inches with a repeatability of 0.004 inches. For the leak detection application it is necessary to detect a change from dry floor to some minimum level of liquid accumulation. Since the principal of operation is buoyancy, sufficient 1 iquid must be present to "float" the displacer before a change in level is detected. Testing of this minimum detectable level is the first step in this activity as described in the next section. The detection threshold can be improved by design of the displacer and by changing the force sensitivity of the instrument. From both an operational and maintenance perspective it is advantageous to use the same hardware and settings as the gauges presently in use for waste level measurement.

\subsection{WORK SCOPE}

This task includes preliminary testing, installation of one Enraf 854 level gauge in the annulus of SY-102 and subsequent installation of eight additional gauges contingent on successful operation of the initial gauge. The gauges will be connected via an Enraf Communications Interface Unit (CIU) to the Tank 
TWR-4092, REV 0

Monitoring and Control System (TMACS). Included in the final installation of all nine gauges will be connection to the existing local alarm annunciator.

The annunciator will activate if any of the Enraf gauges detects the presence of 7 iquid.

The demonstration gauge will not be connected to the existing annulus alarm system, however, the evaluation period will include periodic examination of the local (at the gauge) alarm status as well as continuous monitoring by the TMACS. During the demonstration phase the device will not be used for satisfying the requirements of Limited Condition for Operation (LCO) 3.2 .6 as defined in the Technical Safety Requirements (TSR). See PHMC, 1997b. However, alarms will be investigated as potential leading indications of a leak. The task also includes the generation of any required calibration and maintenance procedures and associated data sheets. Final functional testing will be performed.

\subsection{REQUIREMENTS}

The primary tank leak detection systems are Safety Class (SC) for the flammable gas deflagration and the surface leak resulting in a pool accidents. The applicable LCO is 3.2.6. See PHMC, 1997b. The initial Enraf 854 installed in the annulus of SY-102 will not be used for performing LCO 3.2.6 and will therefore not be a SC Structure, System or component (SSC). The design and installation must conform to SC requirements, however, since they may be subsequently used for TSR compliance.

\section{Safety Function}

The safety functions for the primary tank leak detectors are expressed somewhat differently for each of the above accidents in the Safety Analysis (Section 5.0) in the Bas is for Interim Operation (BI0). See PHMC, 1997a Tables 5.3.2.14-2 and 5.3.2.18-3. The TSR (Bases 3.2.6) however provides an OPERABILITY description that is more specific. The requirement is that:

An OPERABLE primary tank leak detection system consists of at least one conductivity probe (as described in the Background) installed at a location that enables it to detect a leak ( $i$. e. within 1.0 in. from the bottom of the annulus) or a CAM system...

The safety function could be met therefore with an Enraf 854 provided it is sensitive to less than one inch of waste accumulation. Appropriate revisions to the authorization basis will also be required to accept the use of the 854 for performance of the LCO requirement.

Environmental Monitoring

The Washington State Administrative Code (WAC-173-303-640) requires leak detection for dangerous wastes. The Washington State Department of Ecology (WDOE) and Lockheed Mart in Hanford Company have negotiated a consent agreement (PCHB, 1999) that provides a set of compliant requirements for application to the primary tank leak detectors. The following requirements are derived from the consent agreement. 
$0 \quad$ There shall be three detectors in each annulus spaced approximately 120 degrees apart. The probes may operate on the principle of conductivity or other principle of equal or better design.

- The device shall be capable of detecting an increase in liquid of $1 / 4$ inch or 1ess.

o The detectors shall be set to detect at $1 / 4$ inch or less from the bottom of the annulus with normal engineering tolerance.

The sensitivity to increase in liquid will be established using water with a specific gravity of 1.0 since this is the minimum specific gravity expected for any waste leak.

Environmental Conditions

The design ambient temperature range for equipment shall be as follows:

$\begin{array}{lr}\text { Outdoor } & -25^{\circ} \mathrm{F} \text { to } 115^{\circ} \mathrm{F} \\ \text { Buildings } & 50^{\circ} \mathrm{F} \text { to } 95^{\circ} \mathrm{F}\end{array}$

The outdoor ambient temperature is based on historical weather extremes as discussed in PHMC, 1998 . The Enraf 854 is rated for operation over a temperature range of $-40^{\circ} \mathrm{F}$ to $185^{\circ} \mathrm{F}$. Any associated equipment and hardware shall be selected and designed to meet the requirement above.

Natural Phenomena Hazards

As directed in the referenced letter (Raymond, 1998) DOE 6430.1A design criteria (DOE, 1989) need only be applied to the specific SSC design attribute(s) that are used to perform or maintain the safety class safety function(s) identified in the TWRS authorization basis. There is no $\mathrm{BIO}$ defined safety function for the leak detectors associated with Natural Phenomena Hazards (NPH). As such, the design requirements in HNF-PRO-097 (PHMC, 1997c) for NPH are applied based on Performance Category (PC) 1 . For design loads this is equivalent to Uniform Building Code (UBC) requirements. As such, no NPH qualification will be performed.

Sinqle Failure Criterion and Redundancy

DOE 6430.1A, Section 1300-3.3 (DOE 1989) requires the following with regard to single failures:

The design shall ensure that a single failure does not result in the loss of capability of a safety class system to accomplish its required safety functions.

Although the design, as discussed below, is believed to meet the intent of this requirement, there are other TSR controls that provide the required redundancy as discussed in Raymond, 1998.

This design consists of redundant (3) leak detectors spaced at approximately equal distances around the annuli of the tanks. Any one of the detectors can independently generate an alarm and failure of any one will not preclude the others from alarming. Although there is a common alarm, it is designed in a fail-safe manner. Loss of power (below) or open faults in the alarm transmitting cable will result in activation of the alarm. 
TWR-4092, REV 0

Loss of Power

DOE 6430.1A, Section 1660-99.0.1 (DOE 1989) requires that:

For safety class items that require electric power to perform their safety functions, the design shall provide safety class emergency electric power systems ...

The alarm circuit shall be designed such that loss of power will result in an alarm. The alarming relays used in the 854 can be configured for either normally energized or normally de-energized. Using the normally energized condition will provide the alarm on loss of power.

Ignition Control Sets The TWRS Technical Safety Requirements (PHMC, 1997b) Administrative Control 5.10 imposes ignition source controls on equipment in Ex-Tank and Dome Intrusive areas. There are no controls on the annulus space. In the event the conditions within the annulus of a tank changed (e.g. leak from the primary) and controls are imposed, the Enraf 854 meets the most stringent of the Ignition Source Controls (ISC).

\section{Other Requirements}

The gauges will be connected to the TMACS via an Enraf CIU and will alarm at the TMACS operator stations for change in level above the set point. In addition, the Enraf will generate an alarm locally based on the set point. This alarm will be combined with the existing conductivity alarm at the instrument building.

\subsection{TASK DESCRIPTIONS}

The following main tasks will be performed in support of this activity. Each task is described and responsible organizations and/or personnel have been identified.

Cognizant Engineering and Design Authority

The Cognizant Engineer responsible for the overall upgrade activity is $\mathrm{J}$. $\mathrm{H}$. Huber. C. C. Scaief III will provide technical assistance. R. E. Larson will be the responsible Cognizant Manager. The facility Cognizant Engineer will be M. H. Brown. The Design Authority for the facility will be R. W. Reed and C. C. Scaief III will be Design Authority for the TMACS connections.

\section{Design Activities}

The installation design will consist of Engineering Change Notices (ECN) to existing drawings. The ECNs and as-built drawings will be prepared by Cogema Engineering or other qualified design agent but will be released by Lockheed Mart in Hanford. K. E. Carpenter will provide the technical interface for the design activities. The responsible Cognizant Engineer for design will be $\mathrm{J}$. $\mathrm{H}$. Huber. Design verification will be required and the method will be by formal design review for those systems that are safety class. For ECNs not affecting the safety function other design verification methods may be used subject to approval by the Design Authority. A USQ screening of the design will also be required. There is an existing Certified Vendor Information (CVI) file on the Enraf 854 and no new CVI file will be created. 
TMACS Software

The TMACS software will be modified to read the Enraf level gauges and provide the appropriate alarms and display screens. This work will be performed by the Software Development and Integration group of Lockheed Martin Services Incorporated (LMSI). The Cognizant Engineer for this activity will be M. J. Holm. A task order will be required to fund the software modification performed by LMSI personnel.

\section{Plant Forces Work Review}

A Plant Forces Work Review will be performed to determine whether installation activities will be by $\mathrm{Pl}$ ant Forces or Construction Forces. The Production Support organization will be responsible for preparing the work review and obtaining resolution.

\section{Work Package Preparation}

The work package for fabrication, procurement and installation will be prepared by the Production Support organization. The Enraf 854 gauges will be procured as safety class and will include Commercial Grade Item (CGI) dedication. The CGI dedication forms will be prepared by the Cognizant Engineer and approved by the Design Authority.

\section{Procedures}

The functional/operational test procedures for the annulus leak detectors will be revised to reflect any changes necessary as a result of the installation of the Enraf gauges. In addition, a calibration and an operating procedure will be written. Writing of new procedures and revision of the procedures and data sheets will be performed by Maintenance and Surveillance Engineering and the Procedures Group. This will occur by Procedure Change Authorization (PCA) or by a complete revision depending on the extent of the changes required.

\section{Authorization Basis}

Final installation will (assuming successful demonstration of the Enraf) result in new annulus leak detectors of a different type than presently used. In order to use the detectors for meeting LCO 3.2.6, the BIO and TSRs will require revision. This will be the responsibility of the Safety Analysis group of TWRS Nuclear Safety and Licensing.

\section{Testing}

Testing of the Enraf sensitivity and alarm capabilities will be performed prior to the installation of the first unit in SY-102. This testing will be formally documented. The WDOE has also requested a copy of the test report. Final acceptance testing of the new annulus leak detectors will be by successful completion of the associated functional/operational test procedure.

Acceptance for Beneficial Use Appendix B contains an Acceptance for Beneficial Use (ABU) form with deliverable items checked. Responsibilities are also assigned. As required by HNF-IP-0842, Vol IV, 3.12 (PHMC, 1997d), a turnover supporting document will be prepared by the Cognizant Engineer attesting to the completion of the items on the checklist. Approval of the turnover document will constitute final acceptance. 
TWR-4092, REV 0

\subsection{COST AND SCHEDULE}

Cost for the task is contained in the associated TBR package. There is a commitment to the WDOE to install the new leak detectors by December 31, 1999. The schedule is provided in Appendix A.

\subsection{REFERENCES}

DOE, 1989, General Design Criteria, DOE 6430.1A, U. S. Department of Energy, Washington, D. C.

PCHB, 1999, Settlement Agreement and Stipulated Order of Dismissal, PCHB Nos. 98-249 and 98-250, Pollution Control Hearings Board, State of Washington, Olympia, Washington.

PHMC, 1997a, Tank Waste Remediation System Basis for Interim Operation, HNF-SD-WM-BI0-001, Rev. 1-B, Lockheed Mart in Hanford Company, Richland, Washington.

PHMC, 1997b, Tank Waste Remediation System Technical Safety Requirements, HNF-SD-WM-TSR-006, Rev. 0-Q, Lockheed Martin Hanford Company, Richl and, Washington.

PHMC, 1997C, Engineering Design and Evaluation, HNF-PR0-097, Rev. 0, Fluor Daniel Hanford Company, Richl and, Washington.

PHMC, 1997d, Tank Waste Remediation System Administration, HNF-IP-0842, Lockheed Martin Hanford Company, Richland, Washington.

PHMC, 1998, Intrinsically Safe Leak Detector Circuit Design Description, HNF-SD-WM-ER-7362, Lockheed Martin Hanford Company, Rich1 and, Washington.

Raymond, 1998, Letter, R. E. Raymond, LMHC, to M. C. Skriba, FDH, "DOE Order 6430.1A Design Criteria Application for Safety Class Structures, Systems, and Components", LMHC-9852008, dated March 18, 1998.

WAC, 1998, Dangerous Waste Regulations - Tank Systems, Washington Administrative Code 173-303-640, 0Tympia, Washington. 
TWR-4092, REV 0

\subsection{APPENDIX}


TWR-4092, REV 0

APPENDIX A

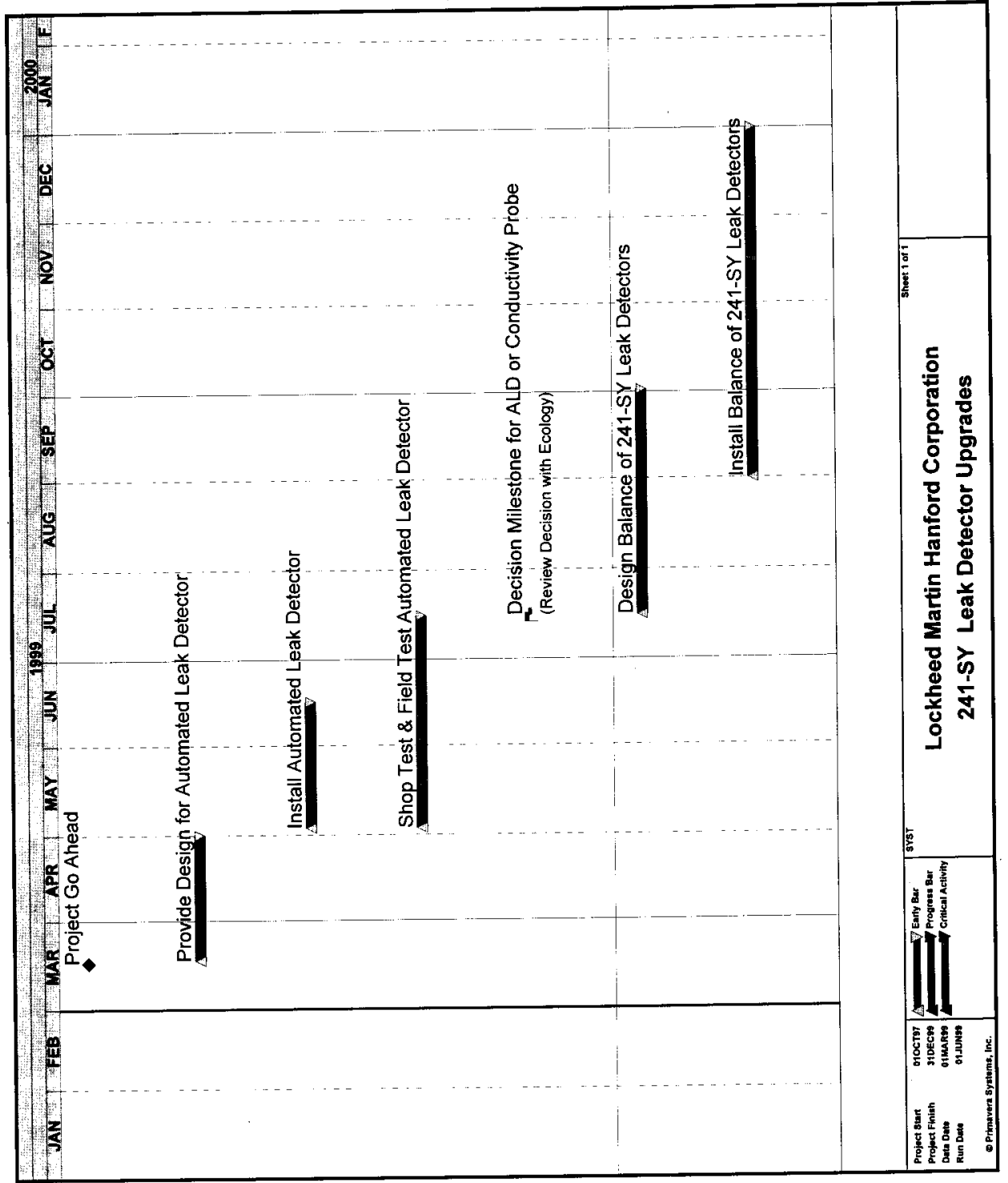


TWR-4092, REV 0

APPENDIX B

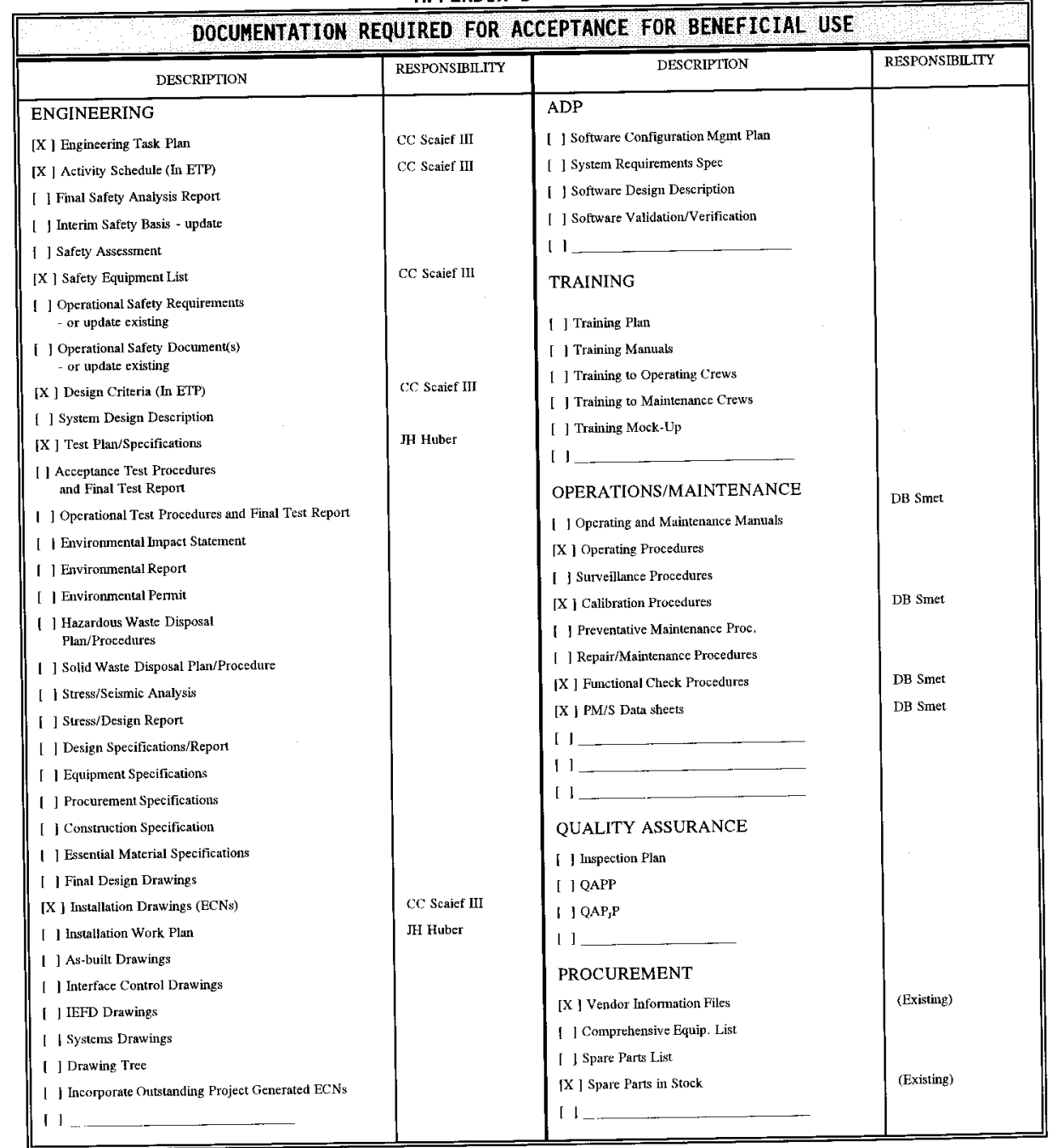




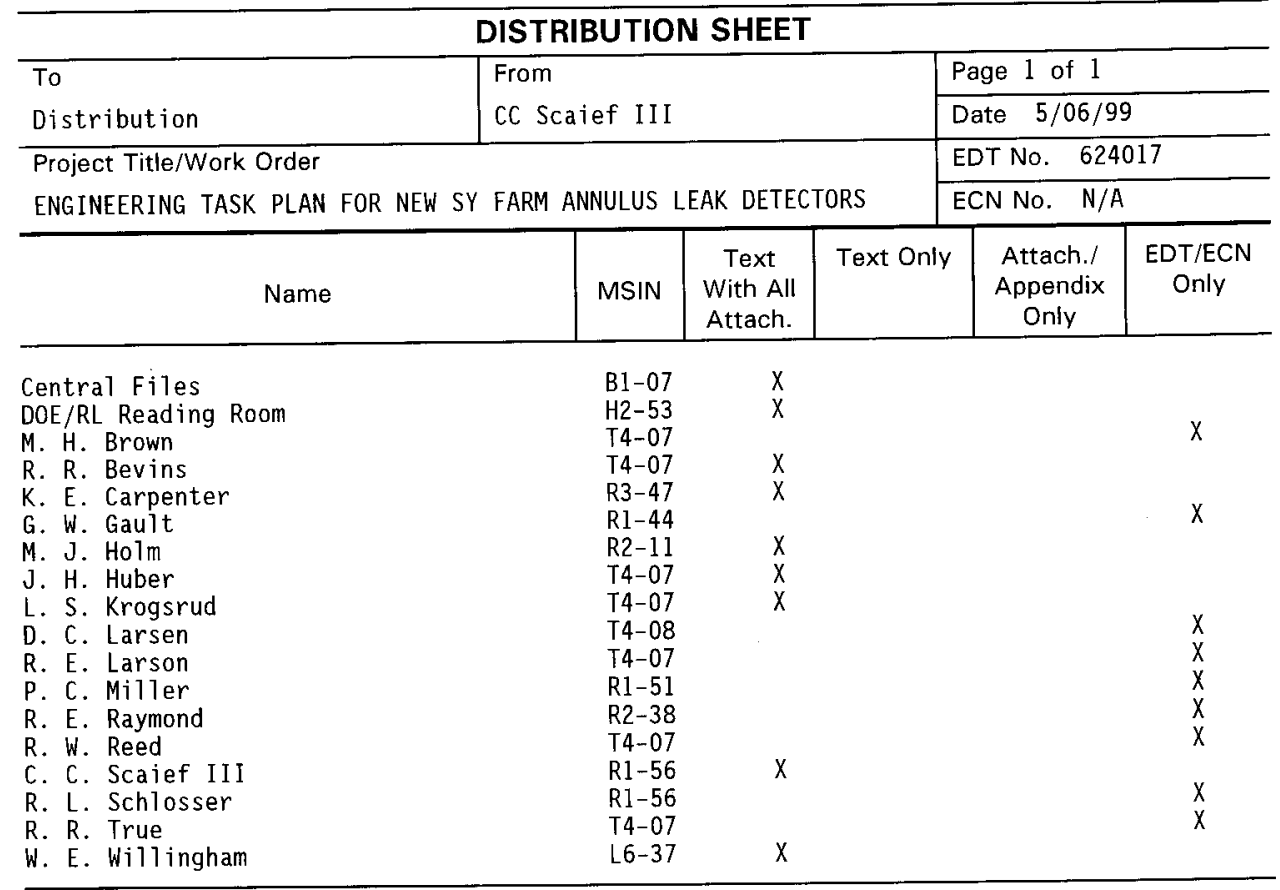

